\title{
PECTIN METHYLESTERASE ACTIVITY DETERMINED BY DIFFERENT METHODS AND THERMAL INACTIVATION OF EXOGENOUS PME IN MANGO JUICE
}

\author{
Determinação da atividade da pectina metilesterase por diferentes métodos \\ e inativação térmica da PME exógena no suco de manga \\ Samantha Lemke Gonzalez', Regina Cristina Aparecida Lima², \\ Eliana Beleski Borba Carneiro ${ }^{2}$, Mareci Mendes de Almeida ${ }^{2}$,Neiva Deliberali Rosso ${ }^{3}$
}

\begin{abstract}
Pectin methylesterase (PME) hydrolyzes methyl ester groups in pectin chains to form carboxylic groups, releasing methanol and $\mathrm{H}_{3} \mathrm{O}^{+}$. The aim of this study was to determine PME activity in samples of pectinases by UV-VIS spectroscopy, to measure the acid and methanol produced in the reaction of pectin with pectinase and to verify the thermal inactivation of exogenous PME in mango juice. The activity of PME in samples of pectinase was determined by potentiometry, UV-VIS spectroscopy, and by the action of alcohol oxidase. The reaction showed greater activity at $\mathrm{pH} 4.0$ to 4.5 and at a temperature of $45^{\circ} \mathrm{C}$. PME activity determined by UV-VIS spectroscopy with bromophenol blue indicator showed a good correlation with the activity determined by potentiometry and with alcohol oxidase. The results showed that bromophenol blue indicators can be used to determine PME activity in samples of pectinases where the optimum $\mathrm{pH}$ is located in the acidic range. The thermal inactivation of exogenous PME in mango juice occurred at $75^{\circ} \mathrm{C}$ for $20 \mathrm{~min}$ of exposure.
\end{abstract}

Index terms: Pectin metilesterase, activity, thermal inactivation, mango juice.

\section{RESUMO}

A PME hidrolisa os grupos metil éster na cadeia da pectina, formando grupos carboxílicos, liberando metanol e $\mathrm{H}_{3} \mathrm{O}^{+}$. Objetivou-se, com o presente estudo, determinar a atividade da PME em amostras de pectinases por espectroscopia Uv-vis para quantificar o ácido e o metanol produzido na reação da pectina com as pectinases e verificar a inativação térmica da PME exógena no suco de manga. A atividade da PME nas três amostras de pectinases foi determinada por potenciometria, espectroscopia Uv-Vis, e pela ação da álcool oxidase. A reação mostrou uma maior atividade em $\mathrm{H}$ de 4,0 a 4,5 e a temperatura de $45^{\circ} \mathrm{C}$. A atividade da PME, determinada por UV-Vis com o indicador azul de bromofenol apresentou uma boa correlação com a atividade determinada por potenciometria e com a álcool oxidase. Os resultados mostraram que o indicador azul de bromofenol pode ser utilizado para determinar a atividade da PME em amostras de pectinases em que o $\mathrm{pH}$ ótimo situa-se na faixa ácida. A inativação térmica da PME no suco de manga ocorreu na temperatura de $75^{\circ} \mathrm{C}$, por 20 min de exposição.

Termos para indexação: Pectina metilesterase, atividade, inativação térmica, suco de manga.

(Received in november 30, 2010 and approved in march 22, 2011)

\section{INTRODUCTION}

Pectin methylesterase (PME), EC 3.1.1.11, is an enzyme that acts mainly in the hydrolysis of methyl ester groups in pectin chains to form carboxylate groups, releasing methanol and $\mathrm{H}_{3} \mathrm{O}^{+}$(JAYANI et al., 2005). According to Zocca et al. (2007) reaction of pectin with PME in the presence of an appropriate indicator at the optimum $\mathrm{pH}$ for the enzyme activity can be monitored by UV-VIS. A study showed that PME activity can be determined with an indicator dye known as bromocresol green (CECI; LOZANO, 1998).

Methanol is toxic to human beings, being an undesirable component in the production of alcoholic drinks and juices in general. Wood e Siddiqui (1971) used UV-VIS spectroscopy to determine methanol levels in $\mathrm{KMnO}_{4}$. Klavons e Bennett (1986) showed that an alcohol oxidase can be used for methanol oxidation and subsequent reaction with 2,4-pentanedione. Mangos e Haas (1997) determined PME activity in reactions with pectin and the methanol released was oxidized by alcohol oxidase.

Riahi e Ramaswamy (2003) evaluated the kinetics of the inactivation of exogenous PME in apple juice. The study showed that an increase in pressure over time has a significant effect on PME inactivation. Plaza et al. (2008) studied the influence of $\mathrm{pH}$ and polyols on the thermal stability of recombinant Aspergillus aculeatus PME. They

2Universidade Federal de Santa Catarina/UFSC - Cidade Universitária Trindade - Florianópolis, SC

¿Universidade Estadual de Ponta Grossa/UEPG - Ponta Grossa, PR

3Universidade Estadual de Ponta Grossa/UEPG - Avenida Carlos Cavalcanti - n. 4748 - 84030-900 - Ponta Grossa, PR - ndrosso@uepg.br 
observed that the PME was thermostable at $50^{\circ} \mathrm{C}$ at pH 5.0 and polyols showed a higher protective effect for the enzyme than sugars. Slavov et al. (2009) investigated the behavior of high methoxy pectin in the presence of a fungal PME and of a PME from orange. In the gel, the degree of methylation decreased slowly with orange PME and rapidly with Aspergillus PME.

Mango fruit can be processed to produce nectar, juice and drinks. According to Ollé et al. (2000) and Kashyap et al. (2001) exogenous pectinolytic enzymes promote a decrease in viscosity, an increase in concentration and clarification of the mango juice nectar. The literature presents few studies using indicators and no studies appear to be available regarding the use of bromophenol blue indicator for the determination of PME activity. Some studies have employed alcohol oxidase and acetyl acetone to quantify the methanol. The aim of this study was to determine PME activity in samples of pectinases by UVVIS spectroscopy to measure the acid and methanol produced in the reaction of pectin with PME, and to verify the thermal inactivation of exogenous PME in mango juice.

\section{MATERIALS AND METHODS}

\section{Materials}

The enzyme preparations Panzym Univers, Pectinex 100L Plus and Panzym Clears (Novozymes) consisted of a mixture of pectinolytic enzymes, predominantly PME and polygalacturonase, produced by submerged fermentation of Aspergillus sp. High methoxyl apple pectin (Herbstreith; Fox) was employed, the water used was deionized and other reagents were analytical grade (Merck, Sigma and Reagen).

\section{Determination of PME activity by titration}

PME activity was determined by titration, using an experimental system of double-walled glass cells coupled with a thermostatized bath (Microchemistry) and a $\mathrm{pH}$ meter Micronal (B474 model) equipped with a combined electrode, calibrated daily with $\mathrm{pH} 4.0$ and 7.0 buffers. The experiments were performed with the controlled addition of $0.05 \mathrm{~mol} \mathrm{~L}^{-1}$ $\mathrm{NaOH}$ free $\mathrm{CO}_{2}$. The experimental solution consisted of $0.150 \mathrm{~g}$ apple pectin, $5.00 \mathrm{mg} \mathrm{mL}^{-1}, 0.100 \mathrm{~mol} \mathrm{~L}^{-1} \mathrm{NaCl}$ and the volume was filled to $30 \mathrm{~mL}$ with deionized water. After solubilization of the components, $50 \mu \mathrm{L}$ of pectinolytic enzyme was added. The temperature and $\mathrm{pH}$ were kept constant. According to Fachin et al. (2002) PME activity is proportional to the initial rate of $\mathrm{NaOH}$ consumption over time $\left(\Delta \mathrm{V}_{\mathrm{NaOH}} / \Delta \mathrm{t}_{\text {time }}\right)$. In this study, the unit used to express the PME activity was mmol L $\mathrm{L}^{-1}$ of carboxylic acid produced per second. The influence of $\mathrm{pH}$ and temperature on the activity of pectinase Panzym Univers was verified. The effect of $\mathrm{pH}$ on enzyme activity was determined for the values of 3.0, 3.5, 4.0, 4.25, 4.5, 5.0 and 5.5, keeping the reaction temperature constant at $45 \pm 0.1^{\circ} \mathrm{C}$. The effect of temperature on the reaction was measured at $25,35,45,55$, 65 and $75^{\circ} \mathrm{C}$, keeping the $\mathrm{pH}$ value constant at 4.0. All tests were performed in duplicate.

\section{Determination of PME activity by UV-VIS}

\section{Acid Quantification}

The $\mathrm{pH}$ of the experimental solution was adjusted to 4.5 and then $150 \mathrm{~mL}$ of a solution of bromophenol blue indicator (Reagen) was added while the temperature was kept constant at $25^{\circ} \mathrm{C}$. Aliquots of $3 \mathrm{~mL}$ of reaction solution were transferred to a quartz cuvette with a $1.0 \mathrm{~cm}$ optical path and $5 \mu \mathrm{L}$ of pectinase was added. The solution was homogenized by vortex, and the kinetics of the reaction were monitored at $592 \mathrm{~nm}$ every $30 \mathrm{~s}$ for $30 \mathrm{~min}$ with a MultiSpec-1501 Shimadzu spectrophotometer. The same conditions were applied to the procedure with the bromocresol green indicator (Reagen). All experiments were conducted in duplicate. The assay was calibrated with a standard curve of D-galacturonic acid for both indicators. The standard curve was built from the Dgalacturonic acid concentration in relation to the absorbance, thus with the exact acid concentration at different times, the PME activity was determined.

\section{Quantification of methanol with alcohol oxidase}

PME activity can be determined by monitoring the release of methanol produced during pectin hydrolysis by the action of the enzyme. In this method, methanol is oxidized to formaldehyde by the action of alcohol oxidase enzymes. It reacts with acetyl acetone or Purpald resulting in compounds that absorb in the visible region. According to Jacobsen e Dickinson (1974), the product of Purpald reactions with formaldehyde is 6-mercapto-s-triazol-(4,3b)-s-tetrazine with maximum absorbance at $550 \mathrm{~nm}$, while the reaction product of acetyl acetone with formaldehyde is 3.5-diacetyl-1,4-dihydro-2,6-dimethylpyridine which absorbs at $412 \mathrm{~nm}$ (NASH, 1953)

\section{Reagent Purpald and Acetyl Acetone}

The reaction system and conditions used to quantify the methanol were described above. After the addition of $50 \mu \mathrm{L}$ of PME to the reaction solution, the $\mathrm{pH}$ was maintained constant at 4.5. Every 2 minutes during the reaction a portion of $1.0 \mathrm{~mL}$ of demethoxylated pectin was withdrawn and placed in an eppendorf tube. This was 
then wrapped in an ice bath to stop PME reactions in the substrate. The methanol released in the reaction was measured according to the method described by Anthon e Barrett (2004). All experiments were performed in duplicate. A standard curve was constructed with known volumes of methanol, 99.8\% $(0-100 \mu \mathrm{L})$ and the absorbance was plotted according to the methanol concentration. From the standard curve the concentration of methanol produced at each time interval was calculated. The PME activity was then calculated from a graph showing the methanol concentration in relation to time.

\section{Determination of exogenous PME residual activity in mango juice}

Mangoes of the Tommy Atkins cultivar were acquired in the local market of the city of Ponta Grossa, PR, Brazil. They were selected regarding color and texture, the size ranged between $9.5-11.7 \mathrm{~cm}$ long and $8.6-10.3 \mathrm{~cm}$ wide, and the weight varied from 394-614g. Juice was extracted with a Britania Turbo Juicer and was then centrifuged to separate off suspended solids, with an Eppendorf Centrifuge 5810R centrifuge at $4^{\circ} \mathrm{C}$ and $3220 \mathrm{~g}$ for 15 minutes. The juice was packaged in $30 \mathrm{~mL}$ bottles and stored in a freezer at $-22^{\circ} \mathrm{C} .10 \mathrm{~mL}$ of preheated juice and $50 \mu \mathrm{L}$ Pectinex 100L Plus were added to a test tube. The vial was then shaken and sealed and subjected to temperatures of $45-75^{\circ} \mathrm{C}$ with a thermostat (Microquimica) for 10, 20 and $30 \mathrm{~min}$ while shaking. After this period the $\mathrm{pH}$ of the juice-PME was recorded and the same value was set for the system containing the substrate. Then the juicePME was added to the reaction and the titration procedure was employed to determine the exogenous PME residual activity in mango juice.

\section{RESULTSAND DISCUSSION}

\section{Determination of optimum pH and temperature for Panzym Univers}

The optimum $\mathrm{pH}$ for the PME in the pectinase sample, that is, the $\mathrm{pH}$ interval where the maximum PME activity occurred, was between 4.0 and 4.5. The same range was determined for samples of Pectinex 100L Plus and Panzym Clears (GONZALEZ; ROSSO, 2011). According to Duvetter et al. (2005) for samples of commercial pectinases obtained from Aspergillus aculeatus and Aspergillus niger the PME optimum $\mathrm{pH}$ was also 4.0 to 4.5. The optimum temperature was $45^{\circ} \mathrm{C}$, which is consistent with the temperature verified by Nikolic e Mojovic (2007) for PME in a sample of pectinase produced by Aspergillus niger.

\section{Determination of PME activity by UV-VIS}

\section{Acid Quantification}

The PME activity in the pectinase samples was determined in the presence of bromophenol blue indicator. In this regard, a study was carried out on the stability of this indicator in the $\mathrm{pH}$ range of 5.0 to 3.7. It was observed that with increasing $\mathrm{pH}$ there was an increase in absorbance, with the maximum at $592 \mathrm{~nm}$. It was also observed that the absorption band does not suffer displacement. Since the bromophenol blue indicator showed good stability in the $\mathrm{pH}$ range studied and the color change is located mainly between 3.0 and $4.6 \mathrm{pH}$, (ATKINS; JONES, 2006) values near the optimum for PME activity (DUVETTER et al., 2005), it was considered as appropriate for use in determining the PME activity.

In the reaction of $\mathrm{PME}$ with pectin at $25^{\circ} \mathrm{C}$ and $\mathrm{pH}$ 4.5, there was a decrease in $\mathrm{pH}$ due to the formation of $\mathrm{H}^{+}$. As $\mathrm{H}^{+}$is combined with the indicator, there is an increase in the concentration of protonated species and a decrease in the concentration of deprotonated species, promoting a proportional decrease in the absorption band at $592 \mathrm{~nm}$ (Figure 1). A study by Hagerman e Austin(1986) determined the PME activity using the bromothymol blue indicator. The color change of this indicator occurs at $\mathrm{pH}$ 6.0-7.6, and the maximum absorbance at $620 \mathrm{~nm}$. The bromothymol blue indicator is suitable for determination of acid produced in reactions where the optimum $\mathrm{pH}$ of the enzyme activity is within the range of the color change of the indicator. It should also be considered that, in addition to enzymatic hydrolysis at $\mathrm{pH}$ values above 7.0, pectin hydrolysis can occur. According to Fayyaz et al. (1995) a reaction conducted at $\mathrm{pH} 8.0$ to determine the PME activity is not safe due to the occurrence of pectin autohydrolysis under alkaline conditions. Considering these factors, bromothymol blue can not be used to determine the PME activity in samples of commercial pectinase in which the optimum $\mathrm{pH}$ lies between 4.0 and 4.5.

Figure 1 shows the behavior of bromophenol blue in different concentrations of D-galacturonic acid and it appears that as the acid concentration increases the absorbance at $592 \mathrm{~nm}$ decreases proportionally. A good linear response between absorbance and concentration of D-galacturonic acid in the presence of bromophenol blue was observed. The correlation coefficient of the straight line was 0.99245 . Equation 1 represents the change in absorbance at $592 \mathrm{~nm}$ as a function of D-galacturonic acid concentration. 
$\Delta \mathrm{A}_{592, \mathrm{pH} 4.5}=0.44903-1713.311 \times\left[\mathrm{H}^{+}\right]$

$\Delta \mathrm{A}=$ Absorbance variation in $592 \mathrm{~nm}$ at $\mathrm{pH} 4.5 ;\left[\mathrm{H}^{+}\right]=\mathrm{H}^{+}$ concentration in $\mathrm{mol} \mathrm{L}^{-1}$

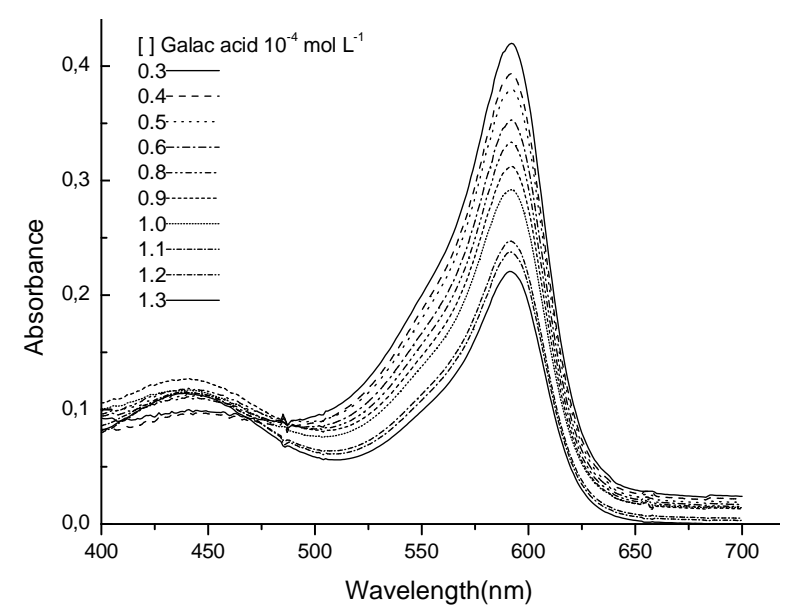

Figure 1 - Behavior of bromophenol blue at different concentrations $\left(0.3-1.3 \times 10^{-4} \mathrm{molL}^{-1}\right)$ of D-galacturonic acid at $25^{\circ} \mathrm{C}$.

The PME activity of three pectinase samples (Pectinex 100L Plus, Panzym Univers and Panzym Clears) was determined at $\mathrm{pH} 4.5$ and $25^{\circ} \mathrm{C}$. To determine the PME activity the standard curve of D-galacturonic acid was used and the concentration of $\left[\mathrm{H}^{+}\right]$was calculated from Equation 1. Thus, from the variation in the acid concentration over the time interval the PME activity was determined. Data from one experiment is shown in Table 1, which shows the variation in the absorbance at $592 \mathrm{~nm}$ for the respective reaction times. The absorbance variation was converted into acid concentration variation, Equation 1, for each time interval.

Table 1 - Absorbance $(\mathrm{A})$ and variation of $\mathrm{A}(\Delta \mathrm{A})$ at 592 $\mathrm{nm}$ versus time, and the $\mathrm{H}^{+}$concentration variation $\left(\Delta\left[\mathrm{H}^{+}\right]\right)$ corresponding to each time interval.

\begin{tabular}{cccc}
\hline Time $(\mathrm{s})$ & $\mathrm{A}$ at $592 \mathrm{~nm}$ & $\Delta \mathrm{A}$ & $\Delta\left[\mathrm{H}^{+}\right]\left(\mathrm{molL}^{-1}\right)$ \\
\hline 0 & 0.809847 & & \\
90 & 0.760955 & $4.889 \times 10^{-2}$ & $2.335 \times 10^{-4}$ \\
180 & 0.724774 & $3.618 \times 10^{-2}$ & $2.409 \times 10^{-4}$ \\
270 & 0.706426 & $1.835 \times 10^{-2}$ & $2.513 \times 10^{-4}$ \\
\hline
\end{tabular}

A linear response was observed for the plot $\Delta\left[\mathrm{H}^{+}\right]$in $\mathrm{mol} \mathrm{L}^{-1}$ versus time in seconds, Equation 1, presenting o correlation coefficient of 0.99537 . The PME activity of pectinase samples shown in Table 2 was calculated from the straight line equation. The slope is equal to $0.9908 \times 10^{-7} \mathrm{~mol} \mathrm{~L}^{-1} \mathrm{~s}^{-1}$ and most of the enzyme activity that can be expressed as $0.9908 \times 10^{-4} \mathrm{mmol} \mathrm{L}^{-1} \mathrm{~s}^{-1}$ of galacturonic acid.

The PME activity in three samples was also determined with the bromocresol green indicator at $\mathrm{pH} 4.5$ and $25^{\circ} \mathrm{C}$. It should be noted that the color change of this indicator occurs in the $\mathrm{pH}$ range of 3.8 to 5.4. From the standard curve of this indicator with the D-galacturonic acid and Equation 2, the PME activity for each sample of pectinase was calculated. The curve showed a linear response and the correlation coefficient was 0.9948 .

$\Delta \mathrm{A}_{617, \mathrm{pH} 4.5}=0.1245+393.363 \times\left[\mathrm{H}^{+}\right]$

$\Delta \mathrm{A}=$ Absorbance variation in $617 \mathrm{~nm}$ at $\mathrm{pH} 4.5 ;\left[\mathrm{H}^{+}\right]=\mathrm{H}^{+}$ concentration in $\mathrm{mol} \mathrm{L}^{-1}$.

Table 2 presents the values of PME for the three pectinases samples with both indicators and their respective standard deviations. It can be observed that the PME activity values for the three samples were lower for the bromocresol green indicator in relation to those obtained with the bromophenol blue indicator. These differences can be attributed to the lower sensitivity of bromocresol green, the range of the color change of this indicator and its stability in relation to the $\mathrm{pH}$ at which the pectin reaction in the presence of the enzyme was conducted (VILARIŇO et al., 1993). The $\mathrm{pH}$ of the reaction was 4.5 , close to the optimum $\mathrm{pH}$ of each sample, and within the $\mathrm{pH}$ range at which the indicator changed color, that is, from 3.8 to 5.4. For both indicators the color stability was observed for $20 \mathrm{~min}$ in the pectin solution at $\mathrm{pH} 4.5$ and $25^{\circ} \mathrm{C}$ and with constant ionic strength. It was found that the color of the bromocresol green indicator in the reaction with pectin did not remain constant, the absorbance of the solution varied even in the absence of PME. On the other hand, bromophenol blue changes color in the $\mathrm{pH}$ range of 3.0 to 4.6 , the region closest to $\mathrm{pH} 4.5$ at which the reaction was conducted. The color of this indicator remained constant throughout the period of the reaction. Therefore, the data obtained for bromophenol blue is considered to be more reliable. 
Table 3 shows the PME activities, for the three samples of pectinases obtained from the procedures by UV-VIS and titration at $25^{\circ} \mathrm{C}$ and $\mathrm{pH} 4.5$. In the UV-VIS spectroscopy study, the bromophenol blue indicator showed good stability in solution with pectin for a reaction of $20 \mathrm{~min}$. The PME activity determined by this procedure shows good correlation when compared with the values obtained from the $\mathrm{NaOH}$ volume variation versus the time variation, $\Delta \mathrm{V}_{\mathrm{NaOH}} / \Delta \mathrm{D}_{\text {time }}$ and $\mathrm{pH}$ variation versus the time variation $\Delta \mathrm{pH} / \Delta_{\text {time }}$ (GONZALEZ; ROSSO, 2011).

\section{PME activity and methanol quantification}

\section{Purplad}

To the reaction of methanol with alcohol oxidase in the presence of the reagent Purpald at $25^{\circ} \mathrm{C}$, a linear increase in absorbance with increasing concentration of methanol $[\mathrm{MeOH}]$ was observed (Equation 3). The correlation coefficient of the curve was 0.98743 . The PME activity was then calculated and is represented in Table 4.

$$
\Delta \mathrm{A}_{550, \mathrm{pH} 7.15}=0.00732+215.99694 .[\mathrm{MeOH}]
$$

$\Delta \mathrm{A}=$ Absorbance variation in $412 \mathrm{~nm}$ at $\mathrm{pH} \mathrm{4.5}$; $[\mathrm{MeOH}]=$ methanol concentration in $\mathrm{mol} \mathrm{L}^{-1}$.

\section{Acetyl Acetone}

A standard curve with good linear response can be obtained for methanol in the presence of alcohol oxidase and acetyl acetone (ANTHON; BARRETT, 2004).
For a standard curve of methanol with acetyl acetone at $25^{\circ} \mathrm{C}$ and $\mathrm{pH} 4.5$, it was observed that with increasing $[\mathrm{MeOH}]$ there is also a linear increase in absorbance (Equation 4). The correlation coefficient of the curve was 0.97354 .

$\Delta \mathrm{A}_{412, \mathrm{pH} 4.5}=-0.02931+81.63622 \times[\mathrm{MeOH}]$

$\triangle \mathrm{A}=$ Absorbance variation in $412 \mathrm{~nm}$ at $\mathrm{pH} 4.5$; $[\mathrm{MeOH}]=$ methanol concentration in $\mathrm{mol} \mathrm{L}^{-1}$.

During the reaction of demethoxylated pectin, in presence of alcohol oxidase and acetyl acetone, the absorbance for each 2 minute interval was obtained. From the standard curve, the $[\mathrm{MeOH}]$ produced at each time interval was calculated. The activity in the sample of Pectinex 100L Plus was 1.073 x $10^{-4} \mathrm{mmol} \mathrm{L}^{-1} \mathrm{~s}^{-1}$ (Table 4).

The PME activity value obtained $3.602 \times 10^{-4}$ mmol L-1 $\mathrm{s}^{-1}$ with the reagent Purpald was more than three times the value obtained $1.073 \times 10^{-4} \mathrm{mmol} \mathrm{s}^{-1}$ with the reagent acetyl acetone. The Purpald reagent should be prepared in $0.5 \mathrm{~mol} \mathrm{~L}^{-1} \mathrm{NaOH}$ solution, using a highly basic medium (ANTHON; BARRETT, 2004). When this reagent was used after the reaction of alcohol oxidase with demethoxylated pectin in buffer solution, the strongly basic Purpald solution offset the 7.15 buffer solution. It was found that the $\mathrm{pH}$ of the reaction containing the buffer, demethoxylated pectin, alcohol oxidase, Purpald and deionized water was above 12 . Thus the reaction condition provokes hydrolyze and it alters the results. After the

Table 2 - PME activity determined by UV-VIS with the two indicators at $\mathrm{pH} 4.5$ and $25^{\circ} \mathrm{C}$.

\begin{tabular}{ccc}
\hline & PME Activity $\left(\mathrm{mmol}^{\left.-\mathrm{L}^{-1} \mathrm{~s}^{-1}\right)}\right.$ \\
\hline Enzyme/ Indicators & bromophenol blue & bromocresol green \\
\hline Pectinex 100L Plus & $0.950 \times 10^{-4} \pm 0.01$ & $1.347 \times 10^{-5} \pm 0.02$ \\
Panzym Univers & $1.015 \times 10^{-4} \pm 0.01$ & $2.730 \times 10^{-5} \pm 0.03$ \\
Panzym Clears & $1.343 \times 10^{-4} \pm 0.01$ & $3.538 \times 10^{-5} \pm 0.02$ \\
\hline
\end{tabular}

Table 3 - PME Activities obtained from the different procedures at $25^{\circ} \mathrm{C}$ and $\mathrm{pH} 4.5$.

\begin{tabular}{cccc}
\hline & \multicolumn{3}{c}{ PME Activity $\left(\mathrm{mmol}^{\mathrm{S}}{ }^{-1}\right)$} \\
\hline Enzyme / Methods & bromophenol blue & $\Delta \mathrm{V}_{\mathrm{NaOH}}{ }^{\mathrm{a}}$ & $\Delta \mathrm{pH}^{\mathrm{a}}$ \\
\hline Panzym Clears & $1.343 \times 10^{-4} \pm 0.01$ & $1.080 \times 10^{-4} \pm 0.01^{\mathrm{a}}$ & $1.291 \times 10^{-4} \pm 0.01^{\mathrm{a}}$ \\
Pectinex 100L Plus & $0.950 \times 10^{-4} \pm 0.01$ & $0.941 \times 10^{-4} \pm 0.01^{\mathrm{a}}$ & $1.157 \times 10^{-4} \pm 0.01^{\mathrm{a}}$ \\
Panzym Univers & $1.015 \times 10^{-4} \pm 0.01$ & $0.881 \times 10^{-4} \pm 0.01$ & $0.904 \times 10^{-4} \pm 0.01$ \\
\hline
\end{tabular}

${ }^{\mathrm{a} G o n z a l e z ~ e ~ R o s s o ~(2011) . ~}$ 
addition of the Purpald the reaction was conducted at $30^{\circ} \mathrm{C}$ for $30 \mathrm{~min}$ (ANTHON; BARRETT, 2004), the period of time for which Purpald reacts with formaldehyde. As the medium is highly basic, the possibility of affecting the pectin hydrolysis, producing more methanol, should not be ruled out. The system contains alcohol oxidase, which oxidizes methanol to formaldehyde, and this then reacts with Purpald resulting in increased concentration of methanol and consequently an apparent increase in the PME activity. According to Ly-Nguyen et al. (2002) the autohydrolysis of pectin must be considered when the PME activity is determined at temperature and $\mathrm{pH}$ values above $50^{\circ} \mathrm{C}$ and 6.5 , respectively. On the other hand, Arbaisah et al. (1997) noted that PME activity measurements performed above $\mathrm{pH} 9.0$ are not reliable due to the de-esterification reaction occurring in the alkaline medium. In the determination of methanol with acetyl acetone, the reagents used did not alter the $\mathrm{pH}$ of the system, which remained at 4.35 . Thus, it can be affirmed that only the methanol produced by the action of PME was detected.

Table 4 shows the values for the PME activity in samples of Pectinex 100L Plus determined by various procedures. It can be observed that the activity value determined using acetyl acetone to detect methanol was similar to values obtained by potentiometric procedures and through spectroscopic detection of the concentration of $\mathrm{H}^{+}$using the bromophenol blue indicator.
Table 4 - PME activity in Pectinex 100L Plus samples determined by different methods at $25^{\circ} \mathrm{C}$ and $\mathrm{pH} 4.5$.

\begin{tabular}{lc}
\hline \multicolumn{1}{c}{ Method } & PME Activity $\left(\mathrm{mmol}^{-1}\right)$ \\
\hline Purpald & $3.602 \times 10^{-4}$ \\
Acetyl acetone & $1.073 \times 10^{-4}$ \\
Bromophenol blue indicator & $0.950 \times 10^{-4}$ \\
$\Delta \mathrm{pH}^{\mathrm{a}}$ & $1.157 \times 10^{-4}$ \\
$\Delta \mathrm{V}_{\mathrm{NaOH}}{ }^{\mathrm{a}}$ & $0.941 \times 10^{-4}$ \\
\hline
\end{tabular}

${ }^{\mathrm{a}}$ Gonzalez e Rosso (2011).

\section{Determination of exogenous PME residual activity in mango juice}

After centrifugation of the mango juice, the $\mathrm{pH}$ remained at 4.50 and the soluble solids at $16^{\circ}$ Brix. Figure 3 shows the thermal stability of the mango juice in the presence of the commercial sample of pectinase (Pectinex 100L Plus). It was observed that for the thermal treatment at $45^{\circ} \mathrm{C}$ the exposure period $(10,20$ and $30 \mathrm{~min})$ did not influence PME activity, as this is the optimum temperature for enzyme activity. However, with increasing temperature there was a decline in activity: at $50^{\circ} \mathrm{C}$ for $10 \mathrm{~min}$ of exposure the residual activity was $72.3 \%$, for $20 \mathrm{~min}$ it reduced to $61 \%$, and for $30 \mathrm{~min}$ it fell to $47 \%$. At $60^{\circ} \mathrm{C}$, for 10,20 and $30 \mathrm{~min}$ the residual activity values were $59.6 \%$, $47.6 \%$ and $31.9 \%$, respectively. For treatments at $65^{\circ} \mathrm{C}$ the residual activity was around $30 \%$ for all exposure periods and at $70^{\circ} \mathrm{C}$ for 20 and $30 \mathrm{~min}$ of exposure the

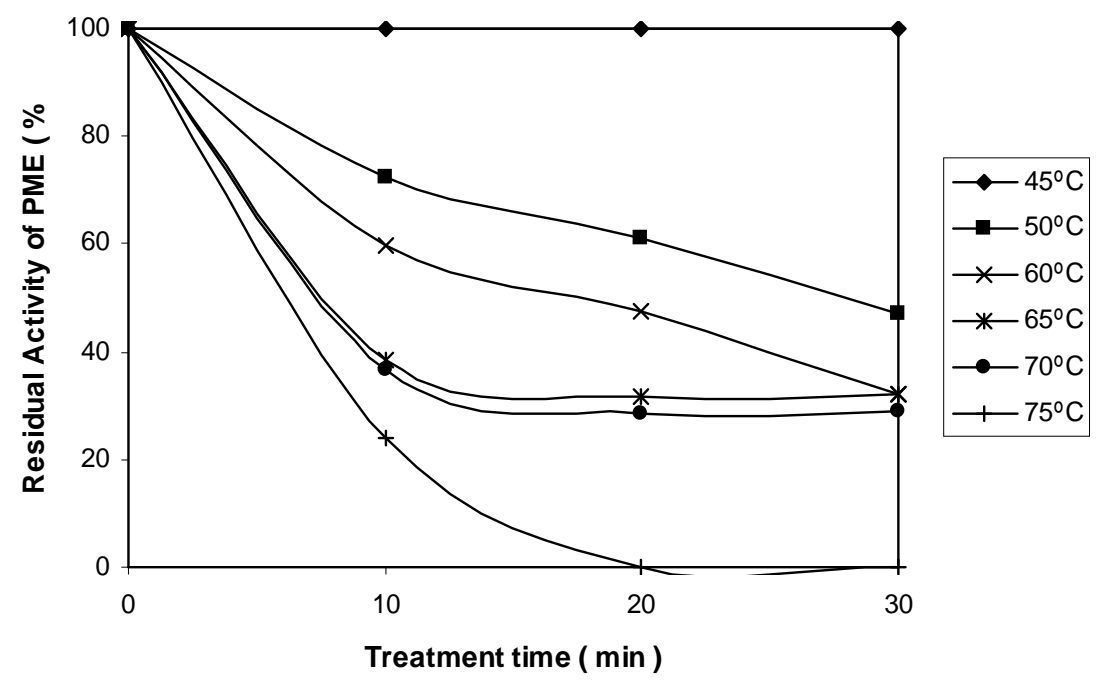

Figure 2-Exogenous PME residual activity in mango juice, $5.0 \mathrm{mg} \mathrm{mL}^{-1}$ of apple pectin, at $\mathrm{pH} 4.0,45^{\circ} \mathrm{C}$ and $0.100 \mathrm{~mol} \mathrm{~L}^{-1} \mathrm{NaCl}$, applying different treatments of temperature plus time.

Ciênc. agrotec., Lavras, v. 35, n. 5, p. 987 -994, set./out., 2011 
activity remained at around $29 \%$. When the temperature was raised to $75^{\circ} \mathrm{C}$ for $10 \mathrm{~min}$ it was observed that the residual activity was $24.1 \%$, however, for $20 \mathrm{~min}$ of exposure there was complete inactivation. A study showed that treatment at $66^{\circ} \mathrm{C}$ for $2.5 \mathrm{~min}$ in apple juice with exogenous PME was sufficient for complete inactivation (WILINSKA et al., 2008). Such differences of temperature and time for complete PME inactivation might be due to the distinct composition of Apple and mango juices. According to Seymour et al. (1991) carbohydrates exert a protective effect on the enzyme (PME). This protective effect is dependent on the chemical composition of the juice under study.

The results obtained in the study on PME thermal inactivation in the presence of mango juice, with thermal treatment at $70^{\circ} \mathrm{C}$ for 10,20 and $30 \mathrm{~min}$ of exposure, show that the residual activity decreased from 36.8 to $29 \%$. In the thermal treatment of the commercial PME, in the absence of mango juice under the same conditions, PME residual activity fell from $29.9 \%$ to $10.0 \%$ (GONZALEZ; ROSSO, 2011). According to Seymour et al. (1991) this difference in the values for the residual PME activity is due to the presence of mango juice, in which the carbohydrates a protective effect on the enzyme (PME). This protective effect is dependent on the chemical composition of the juice in the study.

\section{CONCLUSION}

PME activity in three samples of pectinases (Pectinex 100L Plus, Panzym Clears and Panzym Univers) at $25^{\circ} \mathrm{C}$ and $\mathrm{pH} 4.5$, was determined by UV-VIS spectroscopy with bromophenol blue indicator. It was concluded that this indicator can be used to determine the PME activity in samples of pectinases in which the optimum $\mathrm{pH}$ is located in the acidic range. Data obtained from the use of the reaction of demethoxylated pectin with PME to quantify the methanol and acetyl acetone showed good agreement with those obtained from the procedures used in this study. The determination of methanol with this reagent did not alter the $\mathrm{pH}$ of the system, thus it can be affirmed that the methanol detected was produced only by the action of PME. Thermal inactivation of exogenous PME (Pectinex 100L Plus) in mango juice occurred at $75^{\circ} \mathrm{C}$ with 20 min of exposure.

\section{ACKNOWLEDGMENTS}

The authors are grateful for the financial support of the CAPES and Fundação Araucária.

\section{REFERENCES}

ANTHON, G.E.; BARRETT, D.M. Comparison of three colorimetric reagents in the determination of methanol with alcohol oxidase: application to assay of pectin methylesterase. Journal of Agricultural and Food Chemistry, Washington, v.52, p.3749-3753, 2004.

ARBAISAH, S.M. et al. Purification and properties of pectinesterase from soursop (Anona muricata) pulp. Food Chemistry, Chicago, v.59, p.33-40, 1997.

\section{ATKINS, P.; JONES, L. Princípios de química:} questionando a vida moderna e o meio ambiente. 3.ed. Porto Alegre: Bookman, 2006. 965p.

CECI, L.; LOZANO, J. Determination of enzymatic activities of commercial pectinases for the clarification of apple juice. Food Chemistry, Chicago, v.61, p.237-241, 1998.

DUVETTER, T. et al. Kinetics of papaya pectinesterase. Food Chemistry, Chicago, v.53, p.129-135, 1995.

GONZALEZ, S.L.; ROSSO, N.D. Determination of pectin methylesterase activity of commercial pectinases and study of the inactivation kinetics through two potentiometric procedures. Revista de Ciência e Tecnologia de Alimentos, Campinas, v. 31, p. 412-417 2011.

HAGERMAN, A.E.; AUSTIN, P.J. Continuous spectrophotometric assay for plant pectin methyl esterase. Journal of Agricultural and Food Chemistry, Washington, v.34, p.440-444, 1986.

JACOBSEN, N.W.; DICKINSON, R.G. Spectrometric assay of aldehydes as 6-mercapto-3-substituted- $s$ triazolo(4,3-b)-s-tetrazines. Analytical Chemistry, Washington, v.46, p.298-299, 1974.

\section{JAYANI, R.S.; SAXENA, S.; GUPTA, R. Microbial pectinolytic enzymes: a review. Process Biochemistry, London, v.40, p.2931-2944, 2005.}

KASHYAP, D.R. et al. Applications of pectinases in the commercial sector: a review. Bioresource Technology, Amsterdam, v.77, p.215-227, 2001.

KLAVONS, J.A.; BENNETT, R.D. Determination of methanol using alcohol oxidase and its application to methyl ester content of pectins. Journal of Agricultural and Food Chemistry, Washington, v.34, p.597-599, 1986. 
LY-NGUYEN, B. et al. Strawberry pectin methylesterase (PME): purification, characterization, thermal and highpressure inactivation. Biotechnology Progress,

Washington, v.18, p.1447-1450, 2002.

MANGOS, T.J.; HAAS, M.J. A spectrophotometric assay for the enzymatic demethoxylation of pectin and the determination of pectinesterase activity. Analytical Biochemistry, New York, v.244, p.357-366, 1997.

NASH, T. The colorimetric estimation of formaldehyde by means of the Hantzsch reaction. Biochemical Journal, London, v.55, p.416-421, 1953.

NIKOLIC, M.V.; MOJOVIC, L. Hydrolysis of apple pectin by the coordinated activity of pectic enzymes. Food Chemistry, Chicago, v.101, p.1-9, 2007.

OLLÉ, D. et al. Enzymatic degradation of cell wall polysaccharides from mango (Mangifera indica L.) puree. Journal of Agricultural and Food Chemistry, Washington, v.48, p.2713-2716, 2000.

PLAZA, L. et al. Influence of environmental conditions on thermal stability of recombinant Aspergillus aculeatus pectin methylesterase. Food Chemistry, Chicago, v.111, p.912-920, 2008.

RIAHI, E.; RAMASWAMY, H.S. High-pressure of apple juice: kinetics of pectin methyl esterase inactivation.
Biotechnology Progress, Washington, v.19, p.908-914, 2003.

SEYMOUR, T.A. et al. Stability of pectinesterase of Marsh White grapefruit pulp. Journal of Agricultural and Food Chemistry, Washington, v.39, p.1075-1079, 1991.

SLAVOV, A. et al. Gelation of high methoxy pectin in the presence of pectin methylesterases and calcium.

Carbohydrate Polymers, Barking, v.77, p.876-884, 2009.

VILARIÒO, C. et al. Spectrophotometric method for fungal pectinesterase activity determination.

Lebensmittel-Wissenchaft und Technologie, London, v.26, p.107-110, 1993.

WILINSKA, A. et al. Thermal inactivation of exogenous pectin methylesterase in apple and cloudberry juices. Journal of Food Engineering, Davis, v.85, p.459-465, 2008.

WOOD, P.J.; SIDDIQUI, I.R. Determination of methanol and its application to measurement of pectin ester content and pectin methyl esterase activity. Analytical Biochemistry, New York, v.39, p.418-428, 1971.

ZOCCA, F. et al. Detection of pectin methylesterase activity in presence of methanol during grape pomace storage. Food Chemistry, Chicago, v.102, p.59-65, 2007. 